DOI https://doi.org/10.30525/978-9934-26-110-7-21

\title{
ОНТОЛОГІЧНІ МОДЕЛІ БУТТЯ В НОВЕЛІСТИЦІ ВАЛЕР'ЯНА ПІДМОГИЛЬНОГО
}

\author{
Цюп'як І. К. \\ кандидат філологічних наук, \\ професор кафедри філології та мовної комунікаиії \\ Національний технічний університет \\ «Дніпровська політехніка» \\ м. Дніпро, Украӥна
}

Феномен творення онтологічних моделей Валер'яном Підмогильним визначається тими соціально-історичними обставинами, які змінюючи весь устрій суспільного життя, позначалися на психологічних станах особистості пореволюційної дійсності радянської доби. Автор зображав «ущербну» людину ( а такою іiі робила сама дійсність) в екстремальних психологічних станах в єдиному онтологічному потоку від чуттєвих подій, створюючи художню онтологічну модель буття в такому освітленні, від якого відмовлялися інші письменники.

Розуміння художнього світу В. Підмогильного неможливе без з'ясування екзистенціальних мотивів любові, смерті, голоду, потягу статі тощо. Митець виражає духовну кризу героїв - знеособлення особистості через систему зображувально-виражальних засобів. Герої новел В. Підмогильного гостро відчувають невдоволення світом і собою, самотність, безсилля, руйнування моральних імперативів. Своєю творчістю письменник представляє новий своєрідний вимір духовної культури, яку обумовила дійсність 2-30-х років XX століття. У такому аспекті новели «Добрий Бог», «Гайдамаки», «Військовий літун», «Перед наступом» та інші репрезентують онтологічні новели буття, явлені нам «суворим аналітиком доби». У цій моделі представлено тип безвідповідальної особистості і окреслюється розлоге онтологічне поле їі діяльності: «Ці люди, як і їх батьки, починали сновигати по вулицях міста, забувати про те, що так само помруть, і в шаленій метушні їли, пили, творили культуру, поглибшували науку, будували собі нові мури, кували нові кайдани; жилава ж і костиста рука буття без жалю й радощів шпурляла їх на їхніми ж руками зроблене каміння, проти їх повертала їхню ж науку, здобутками їхньої культури виснажувала їх, , а вони все так само заклопотано бігали по вулицях міста. Сміялись, сподівались і покірно врешті йшли на страту»[1, с. 71$]$. 
Концептуально онтологічні моделі підпорядковані певним авторським установкам, за вірогідність автор не несе відповідальності, бо це насамперед художні моделі, які дають можливість відсторонитися від навколишньої дійсності і подивитися на об'єкт власного спостереження збоку, відмежовуючись від нього, тим часом детальніше їх аналізуючи. Екзистенціальне творення онтологічної моделі буття героїв має психологічні параметри характерологічного портрету доби, яка нівелює особистість. Автор завуальовує свою присутність , натомість на передній план виходить онтологічна модель буття людини як модель конфлікту: 1) суб'єкт-об'єкт ( антиномічна опозиція героя до навколишньої дійсності; 2) суб'єкт - суб'єкт( конфлікт між героями, та протистояння зовнішнього і внутрішнього в людини, морального та аморального); 3) суб'єкт- об'єкт-суб'єкт (через конфлікт з дійсністю розпочинається конфлікт 3 іншими героями); 4) об’єкт - суб'єкт (система сама спричинює конфлікт з особистістю).

Таким чином, через змодельований внутрішній стан переживання

конфлікту своїми героями В. Підмогильний віддзеркалює модель всього суспільства, через одну одиницю відображає ціле.

\title{
Література:
}

1. Підмогильний В. Старець. Підмогильний В. Оповідання. Повісті. Романи. Київ, 1991. 802 с.

DOI https://doi.org/10.30525/978-9934-26-110-7-22

\section{ЕКЗИСТЕНЦІЙНА ПРОБЛЕМАТИКА РОМАНУ МАКСА КІДРУКА «ДЕ НЕМАС БОГА»}

\author{
Чонка Т. C. \\ кандидат філологічних наук, \\ доцент кафедри філології (українське відділення) \\ Закарпатський угорський інститут імені Ференца Ракоиі II \\ м. Берегово, Закарпатська область, Украӥна
}

Предметом даного дослідження $\epsilon$ роман молодого сучасного українського письменника Макса Кідрука (1984 р.н., за фахом інженера-енергетика) «Де немає Бога». У статті здійснено інтерпретацію екзистенційної проблематики твору шляхом пообразного аналізу. 